\title{
A Call to Integrate Economic, Social and Environmental Motives into Guidance for Business Support for the Transition to a Circular Economy
}

\author{
Anne P. M. Velenturf ${ }^{1, *(\mathbb{C})}$, Paul D. Jensen ${ }^{1}{ }^{\mathbb{D}}$, Phil Purnell ${ }^{1}$, Juliet Jopson ${ }^{1}$ and Norman Ebner ${ }^{2}$ \\ 1 School of Civil Engineering, University of Leeds, Leeds LS2 9JT, UK; P.Jensen@leeds.ac.uk (P.D.J.); \\ P.Purnell@leeds.ac.uk (P.P.); S.J.Jopson@leeds.ac.uk (J.J.) \\ 2 Business School, University of Leeds, Leeds LS2 9JT, UK; N.Ebner@leeds.ac.uk \\ * Correspondence: A.Velenturf@leeds.ac.uk
}

Received: 29 September 2019; Accepted: 28 November 2019; Published: 30 November 2019

\begin{abstract}
A broad range of organizations, from small and medium-sized enterprises to large multi-nationals, are interested in adopting circular economy practices. A circular economy can help companies make better use of materials by minimizing the input of natural resources, reducing waste, and optimizing the economic, social, technical and environmental costs and benefits of materials and products throughout their lifecycle. Despite the interest of companies in a circular economy, only $9 \%$ of material flows in the global economy are circular. There is formal guidance for those offering business support with the aim to expedite the transition to a circular economy. However, support measures narrowly confine the role of companies and the motivations of business managers to the economic realms, assuming that companies are solely driven by monetary factors. Conversely, pluralist economic views emphasize the broader role of companies in society: for example, in respect of the well-being of their staff and the communities in which they reside. Indeed, our practical experiences of business support have brought alternative motivations to explore a circular economy to the fore. We argue that business support should stem from a broader conception of the role of business in society. The diverse motivations and willingness of business managers to engage in a circular economy should be investigated further with results feeding into broader and more inclusive business support guidelines in the future to accelerate the transition towards a circular economy.
\end{abstract}

Keywords: circular economy; circular business model innovation; industrial ecology; waste and resource management; sustainable production and consumption; human well-being; corporate social responsibility; regional development; stakeholder engagement; business management

\section{Business and the Uptake of a Circular Economy}

\subsection{The Importance of Accelerating the Transition to a Sustainanble Circular Economy}

Resource overexploitation and waste generation have a critical impact on the environment and human well-being (United Nations Environment Program and International Solid Waste Association 2015; United Nations Environment Program 2016; Raworth 2017). Through its holistic focus on resource conservation, a circular economy has the potential to bring economic activities back within environmental boundaries while strengthening social foundations. As part of a general movement towards more eco-efficient low-impact economies (Simboli et al. 2014), a circular economy brings together various schools of thought, such as industrial ecology, cleaner production, ecological economy, cradle-to-cradle and natural capitalism (Korhonen et al. 2018; Suarez-Eiroa et al. 2019). The European Commission states that: "[i]n a circular economy, the value of products and materials is maintained for 
as long as possible. Waste and resource use are minimised, and when a product reaches the end of its life, it is used again to create further value. This can bring major economic benefits, contributing to innovation, growth and job creation" (European Commission n.d.). It has been shown that circular economy practices can help companies make better use of material resources by minimizing natural resource input and waste generation, and optimizing the economic, social, technical and environmental costs and benefits of materials and products throughout their lifecycle (Velenturf and Jopson 2019). For example, in the case of industrial symbiosis, which is part of circular economy thinking, significant amounts of materials have been reused and recycled through new supply chain connections between industries, providing empirical evidence of the substantial economic and social benefits to business and communities as well as markedly reducing the environmental impact of industry on a national scale (European Union 2015; National Industrial Symbiosis Program 2009, n.d.; Jensen et al. 2011; Jensen 2016). Indeed, circular economy practices are believed to hold great sustainability potential (quantified in Section 4.1) despite recent concerns being raised regarding possibly unsustainable practices that could be implemented under a circular economy banner (Geissdoerfer et al. 2017; Schroeder et al. 2018; Suarez-Eiroa et al. 2019).

A broad range of organizations from small and medium-sized enterprises to large multi-nationals are interested in adopting circular economy practices, such as products-as-a-service, reuse, remanufacturing and the above discussed industrial symbiosis. For example, the Ellen MacArthur Foundation manages the "Circular Economy 100" network where companies, including large multinationals such as Apple, IKEA and McDonalds, exchange knowledge and develop new ways of collaborating in a circular economy (The Ellen MacArthur Foundation 2019), whilst global frontrunners of a circular economy have been stated to include Rolls Royce, BAM and DS Smith (Kiser 2016; The Ellen MacArthur Foundation 2019). Quantifying interest in a circular economy, a survey by Global Compact found that $33 \%$ of CEOs globally are considering the adoption of circular economy practices (Accenture and UN Global Compact 2013). Additionally, in the UK, industry was closely involved in the co-production of priorities and strategies for implementing a circular economy via the Resource Recovery from Waste program ${ }^{1}$ (Velenturf and Purnell 2018; Department for Environment, Food and Rural Affairs 2018). Despite this global business interest and willingness to engage in a circular economy, the circularity of the economy is only believed to be up to $9 \%$, which indicates that there is still a long way to go (Circle Economy 2019).

\subsection{The Necessity of Supporting Businesses in the Uptake of Circular Economy Practices}

Circular economy literature generally agrees that companies require support to develop the knowledge and skills to transform their activities and contribute to a sustainable, circular economy (Velenturf and Jopson 2019). This is particularly true of smaller companies who regularly work at the margins and are not blessed with the time, people or financial resources required to explore the changes for the adoption of more circular operational practices. For these businesses, formal business support services able to profess the benefits of circularity and help businesses implement resource efficiencies, are fundamental to accelerate wider participation in a circular economy. Indeed, while empirical research into circular economy implementation is still in the early stages, the critical role of government in realizing a circular economy has been broadly recognized. This includes for example the creation of amenable governance conditions, enabling secondary resource markets and developing business support networks (Marshall et al. 2018). Relying on business alone for the uptake of circular economy practices is considered unwise, given the speed of change that is required to improve resource use, the large scale of environmental challenges and social inequity, and the difficulty of addressing these in an

1 The Resource Recovery from Waste programme was a £7M strategic investment by the Natural Environment Research Council, the Economic and Social Research Council and the Department for Environment, Food and Rural Affairs to drive radical change in resources and waste management in the UK. See https://rrfw.org.uk/. 
integrated manner from the relatively narrow perspective of individual companies (Vermeulen 2015; Ghisellini et al. 2016). Nevertheless, information on the exact manner in which governments can best support companies in the transition to a circular economy is limited (e.g., Lehtoranta et al. 2011; Madsen et al. 2015). As such it is considered equally important that companies engage with government to express challenges that they are facing and to propose how government could support the uptake of circular economy practices in industry (Velenturf and Purnell 2018).

Effective approaches that motivate and support companies in the uptake of circular economy practices are important for an expedited transition. This article aims to contribute to the on-going development of guidance for business support. Current guidance narrowly confines the role of companies and the motivations of business managers to the economic realms (e.g., European Commission 2016; The Ellen MacArthur Foundation 2015a, 2015b). Conversely, pluralist economic views emphasize the broader role of companies in society (Section 2). Moreover, practical experiences with business support reported in this article brought alternative motivations to explore a circular economy to the fore (Section 3). This communication article argues that business support should stem from a broader conception of the role of business in society. This article calls for further investigation into the diverse motivations of business managers. The results of such studies should be fed into more inclusive business support guidelines with the aim of fully capitalizing on the willingness within the business community to contribute to a circular economy (Section 4).

\section{The Changing Role of Business in Society}

\subsection{Is It Just about the Money?}

In a 1970 New York Times article, the Chicago economist Milton Friedman defended a view he had already developed eight years earlier in his book Capitalism and Freedom (Friedman 1962, 1970): the only responsibility that a business had toward society was the maximization of its profit. To be precise, the responsibility was with the corporate officers as for Friedman the legal entity as such had no responsibility whatsoever. Friedman's view would become highly influential, particularly from the 1980s onward, when it came to dominate both business theory and practice through the concept of shareholder value maximization (Rappaport 1986). The alternative view-stakeholder theory, which maintained that a business's social responsibility extended beyond wealth-maximization for its shareholders-came increasingly under attack. Some, such as Sternberg $(1997,1998)$, even called it 'parasitic' in that it conceded to other parties the right to a 'free lunch' at the rightful owners' expense. Defenders of stakeholder theory countered that even though the pursuit of profit might be essential to the perpetuation of a business, so was the continued well-being and prosperity of its employees, customers and the wider community in which it operated (Greenwood 2001). Management theorists such as Henry Mintzberg (1983) have subscribed to this line of reasoning. Further, empirical evidence has shown that a disregard for stakeholder interests could have negative effects not only for the stakeholder groups involved but also on a business's profitability (e.g., Scholes and Clutterbuck 1998; Whysall 2000). It has also been argued that the adoption of stakeholder friendly principles such as those drawn from industrial ecology might even confer certain competitive advantages on such a business (Hoffman et al. 2014; Simboli et al. 2014).

Some, like Evan and Freeman (1993) would (re-)assign a moral status to business organizations, something that Friedman had denied them. Others have taken such thoughts further. For Post (2003), for example, the corporation was a 'forum for stakeholder interaction' and as such responsible for all stakeholders involved. The emergence of such concepts as 'corporate citizenship' and 'corporate social responsibility' bears testimony to the increasing awareness that businesses have a responsibility to society as a whole, rather than just their shareholders (Moon 1995). Indeed, this view has been institutionalized in the organizational phenomenon commonly known as 'social enterprise', which pursues the goal of delivering social benefits rather than a fervent focus on profit (Doherty et al. 2014). 
Social enterprises move away from allocating decision-making powers only to those who own the capital and instead adopt more participatory organizational structures to deliver social value (Nyssens 2006; Stevens et al. 2015). Social entrepreneurship—and indeed the social aspects of a circular economy (discussed below in Section 2.2) - is under-theorized in academic literature, presenting challenges regarding the definition of social enterprise and the very concept of "social value" itself (Doherty et al. 2014; Stevens et al. 2015). There is however consensus that social enterprises combine social purpose with financial sustainability (Doherty et al. 2014), achieved through trading i.e., the producing and selling of goods and/or services (Stevens et al. 2015). Social purpose can pertain to concerns regarding people and community as well as the environment (Department for Digital, Culture, Media and Sport and Department for Business, Energy and Industrial Strategy 2017). Profits of social enterprises are reinvested into the enterprise itself or paid to a (linked) charitable organization in order to deliver even more social and environmental value (Department for Digital, Culture, Media and Sport and Department for Business, Energy and Industrial Strategy 2017; SEUK 2017).

Social entrepreneurship has become more prominent since the 1990s and represents a significant proportion of the total business environment (Department for Digital, Culture, Media and Sport and Department for Business, Energy and Industrial Strategy 2017; SEUK 2017). In the UK, close to $9 \%$ (471,000, employing ca. $1.4 \mathrm{M}$ people) of small businesses were identified as social enterprises (Department for Digital, Culture, Media and Sport and Department for Business, Energy and Industrial Strategy 2017). Social enterprises are a subset of the $22 \%$ of small businesses in the UK that are 'social-oriented', i.e., companies led by missions to create social (and environmental) value (Department for Digital, Culture, Media and Sport and Department for Business, Energy and Industrial Strategy 2017). Social entrepreneurship is a growing movement, and with maturity comes increases in business size: $10 \%$ are medium-sized companies and $14 \%$ have turnovers of over $£ 1 \mathrm{M}$ per year (SEUK 2017). Social enterprises are outperforming 'mainstream SMEs', i.e., those who are primarily led by economic gain, in terms of turnover growth, innovation, business optimism, start-up rates, diversity in leadership and more (SEUK 2017).

\subsection{Developing the Social Side of a Circular Economy}

So far, circular economy has mainly followed the path of mainstream economics, considering enterprises as entities who are primarily driven by profit and business growth. Circular economy has occupied itself with asserting that its environmental benefits would come with associated economic benefits (e.g., new sales from use of wastes and/or cost savings from reduced waste management), while the emergence of social benefits (e.g., new direct and indirect employment and a healthier living environment) are implied to be a 'given' co-benefit (discussed further below and in Section 4.1). This focus on economy and environment rubbed off on business managers. When asking industry to set priorities for their own contributions to the circular economy transition in the UK, social aspects were virtually absent apart from the need for educating customers about a circular economy and the evolving customer-attitudes that drive change in business practices. Social aspects regarding consumers were considered important but were approached from the perspective that people, and companies alike, are economic rather than social actors in a circular economy (Velenturf and Purnell 2018).

Calls to give social factors a more prominent role in circular economy research and practice have been growing in recent years (Murray et al. 2017; Moreau et al. 2017; Merli et al. 2018). Critique centers on the absence of thinking on how a circular economy can contribute to greater inter and intra-generational equality in terms of social and financial equity and access to resources (Murray et al. 2017; Schroeder et al. 2019). For business, a greater emphasis on social aspects within a circular economy context may mean:

- Taking a holistic perspective by creating environmental quality, social equity and economic prosperity for current and future generations (Kirchherr et al. 2017). With regards to social equity, in particular managing the impacts and benefits for welfare, justice and human rights (Murray et al. 2017; Moreau et al. 2017; Merli et al. 2018; Suarez-Eiroa et al. 2019). 
- Measuring performance against a mix of environmental, social and economic indicators, integrating them into decision-making to enable businesses to address environmental and social challenges and also contribute to achieving the UN Sustainable Development Goals (Global Reporting Initiative 2015; Global Reporting Initiative and UN Global Compact n.d.).

- Innovating business models to integrate costs and benefits to the environment and society into their value proposition, and cost and revenue structure (Velenturf and Jensen 2017).

- Driving behavior change of consumers by promoting responsible, ethical consumption and sufficiency, to reduce consumption at a whole-system level (Bocken and Short 2016; Stahel 2016).

- Playing an active role in shaping governance and a circular society in addition to managing their own company (Dyllick and Muff 2015; Velenturf and Purnell 2018).

\section{A Taste of Practice}

\subsection{Experiences from Regional Business Support Projects}

A number of observations were particularly notable in the engagement of micro, small and medium-sized enterprises (SMEs) ${ }^{2}$ in EU funded projects for regional development (European Union 2019) that aimed to embed more resource efficient circular economy practices into business operations. Practitioners of the Energy Technology Centre ${ }^{3}$ in East Yorkshire (UK) regularly observed that owners of SMEs were content with the scale of their business operations and showed little interest in growing their company. Much of this disinterest derived from not wanting to 'disrupt' their relatively successful businesses in terms of becoming, as they saw it, less personable and more complex to manage. As such, many of the companies engaged by the Energy Technology Centre were less receptive to circularity arguments focused on economic growth. In Cornwall, companies engaged via the Tevi project ${ }^{4}$ were interested in adopting circular economy practices out of strong environmental and social considerations. Business owners wanted to support other local businesses and their communities. They took pride in the "Cornish lifestyle", characterized for example by outdoor living, laidback attitudes, local food and drink, and the pristine, rugged landscape; they wanted to strengthen regional identity through the uptake of circular economy practices. Business owners were less driven by economic motivations during the initial exploration of circular economy. Undoubtedly, any proposed new circular economy practices will have to make business sense, but drivers such as increasing profit and turnover were not the primary motivations for business managers to investigate circular economy. Some of these companies engaged in EU-funded projects focused on a circular economy were, in fact, led by environmental and social missions (as discussed in Section 2.1) and were looking to join up social entrepreneurship with circular economy practices. Social and environmental motivations are not unique to business owners and managers of SMEs, as will be explained in the next section. However, in SMEs there is a better chance that managers are in control to enact their personal drivers within their own companies (Stevens et al. 2015). This means that, within SMEs, there may be a great untapped potential to motivate business owners and managers to adopt circular economy practices when these are aligned with their social and environmental missions.

2 In $2015,99.8 \%$ of European Union businesses not operating within the financial sector were classed as micro (92.8\%), small $(6 \%)$ or medium-sized enterprises (1\%) (European Union 2018). SMEs form the backbone of the economy and host the largest group of business owners and managers to engage in a circular economy transition.

3 The Energy Technology Centre was a European Regional Development Funded business support service that provided East Yorkshire based SMEs with expert consultancy on improving their business operations through the adoption of low carbon technologies and development of resource efficiency and corporate responsibility strategies. Cited observations were documented in an engineering skills gap analysis conducted by the ETC (Jensen 2015).

4 Tevi is an EU-funded project that aims to support SMEs in Cornwall and the Isles of Scilly with expert consultancy, certification and grant funding in order to deliver environmental and economic growth. See https://tevi.co.uk/. 


\subsection{Motivations of Global CEOs}

The 2013 UN Global Compact-Accenture CEO Study on Sustainability offers detailed insight into the personal viewpoints of CEOs and senior business leaders of generally large multi-national companies (Accenture and UN Global Compact 2013). Global Compact is a sustainability scheme that promotes ten principles for good business in the areas of human rights, labor standards, combatting corruption, and the environment. A majority of the CEOs surveyed in the Global Compact study $(67 \%)$ believed that business should do more to solve sustainability challenges. Only $32 \%$ believed that the global economy will meet the growing demands from consumers within environmental limits. This drove many of the CEOs that were consulted for the report to explore circular economy solutions. Companies, it was suggested, were already faced with resource scarcity issues and cost increases: for the majority of companies, resource costs cover a third or more of total business expenditure and had already experienced the adverse effects of resource price volatility. A circular economy was thus seen to offer a solution for both economic and environmental concerns.

Sustainability was generally expected to transform industry, bringing growth and innovation, but CEOs felt that they had driven sustainability as far as they could within current market and governance structures and systems. A call was made for government leadership at global, national and local scales to create the enabling conditions for sustainability and green growth within planetary boundaries and answering to the global sustainable development agenda. The need for government leadership in a circular economy was also confirmed by extensive research by the Resource Recovery from Waste program in the UK, firmly pointing to the necessity for government to intervene in a multitude of manners including business support measures, enacting fiscal tools, and adopting a more holistic measure of progress than GDP for the country as a whole (e.g., Velenturf and Jopson 2019). In some areas this has already occurred with some reports of success. As an example, the European Commission took a direct role, in collaboration with industry stakeholders, in developing what is considered an impactful strategy for increasing the sustainability of plastics throughout its lifecycle (Foschi and Bonoli 2019).

Despite the social-mindedness of CEOs, changing the role of their business in society may not be within their control (Accenture and UN Global Compact 2013). The creation of social value generally does not absolve a company from having to perform against traditional measures of success as a first priority. Augenstein and Palzkill (2016) make a similar observation regarding the challenges to reconcile sufficiency (see Section 2.2) with traditional growth-oriented corporate narratives and business models, balancing short-term economic with long-term sustainability interests. CEOs in the Accenture and UN Global Compact (2013) study point towards the expectations of markets and stakeholders that are holding them back to act more upon sustainability. Management of societal expectations were mostly influenced by consumers, employees and government, and to a lesser extent by communities and a range of other stakeholders. CEOs generally did not recognize that the business board were inhibiting sustainability strategy and, interestingly, neither were the shareholders; although the latter were not recognized as being particularly helpful either.

At the surface CEOs appeared to be primarily driven by economic matters, such as brand value and potential for revenue growth and cost reduction, in their motivations to invest in sustainability and only secondarily by personal motivations. However, there was a clear difference between CEOs of companies that solely focus on their own organization and those who play an active role via other positions in addition to their own organization. Eighty-two percent of CEOs believed they have a responsibility to drive sustainability within their organization and more widely to leave a positive legacy for the next generations, but only a subset of these CEOs managed to be active beyond their organization. Similar to the social entrepreneurs discussed in Section 2.1, CEOs who took wider responsibility in their community outperformed, in terms of traditional business performance metrics, their colleagues who were only maintaining a narrow scope on their company. These CEOs with a broader focus held different motivations, maintained different networks of influencers, and prioritized other subjects for investment, innovation and action. 
A majority of CEOs believed that they held a personal responsibility to lead on sustainable development, and such commitment was seen as a prerequisite to be able to drive sustainability in the corporate arena (Accenture and UN Global Compact 2013). For many CEOs, the personal motivations stemmed from their cultural background in which sustainability efforts were tied to supporting local communities out of philanthropic considerations and acquiring a license to operate for the long-term operation of a business. Indeed, national context and ideologies were seen to shape the behavior of corporations in regard to their wider sustainability attitude and actions (Amor-Esteban et al. 2018). In Japan, CEOs went as far as stating that companies exist for the primary purpose of solving societal issues (Accenture and UN Global Compact 2013). In India, a prevalence of family-owned businesses established close links to local communities and a personal commitment to act upon sustainability. This may not be too dissimilar from the observations made in business support projects in the UK (discussed in Section 3.1). The variety of business perspectives that were driving the desire to adopt a circular economy, observed through practical experience, suggests that there is scope for revisiting the guidance for those who offer business support.

\section{Updating Business Support Guidance for the Facilitation of a Circular Economy}

\subsection{The Size of the Prize}

The uptake of a circular economy has the potential to bring considerable benefits:

- Globally the economic benefits have been forecast to reach $\$ 4.5$ trillion by 2030 , rising to $\$ 25$ trillion by 2050 (Lacy and Rutqvist 2014); compared to a total global economy of $\$ 80$ trillion in 2017 (World Bank n.d.). Low-carbon and resource efficient strategies could result in global greenhouse gas reductions of $63 \%$ by 2050 (Circle Economy 2019).

- Circular economy approaches could benefit the EU economy to the tune of $€ 1.8$ trillion by 2030 (McKinsey and the Ellen Macarthur Foundation 2015), offering a $€ 320$ bn investment opportunity in mobility, food, and the built environment sectors until 2025 (The Ellen MacArthur Foundation 2017). This could result in carbon emission reductions of $48 \%$ across these three sectors by 2030 , and $83 \%$ by 2050 when compared to emission levels in 2012. Growth in jobs could total up to $4 \%$ by 2030 (Stahel 2016).

- In the UK, a circular economy has been conservatively estimated to add $£ 10 \mathrm{bn}$ of value to the economy by 2030 (Business in the Community 2018). Circular economy approaches could reduce emissions by ca. $200 \mathrm{MtCO}$ e by 2032 (Green Alliance and CIE-MAP 2018), making an essential contribution to the UK's decarbonization targets. The potential for employment growth varies between 205,000 and 517,000 additional jobs by 2030 depending on government strategy (Green Alliance and WRAP 2016).

In the period between 2014 and 2020, the EU invested $€ 88 \mathrm{bn}$ into regional development projects for resource efficiency and environmental protection and another $€ 63 \mathrm{bn}$ in the development of a low-carbon economy (European Commission n.d.). These investments and the potential benefits listed above provide a clear impetus for the EU to make the most of the circular economy opportunity. It is essential that effective guidance is available for those who are supporting businesses in the circular economy transition. To that end, the EU has published guidance under the banner of resource efficiency, such as "A framework for Member States to support business in improving its resource efficiency" (European Commission 2015) and "Improving resource efficiency in SMEs" (European Commission 2016). The Ellen MacArthur Foundation has also published extensively on this subject, on their website and in reports such as "Towards a circular economy: Business rational for an accelerated transition" (The Ellen MacArthur Foundation 2015a) and "Delivering the circular economy: A toolkit for policymakers" (The Ellen MacArthur Foundation 2015b). 


\subsection{Provide Guidance for Business Support at Each Stage of the Innovation Process}

Innovation is considered integral to the uptake of new products, services and business models in a circular economy, as illustrated in the European Commission's (2016) guidelines as "A guide for policy makers, stakeholders and managing authorities, who want to support resource efficiency in SMEs and help them reduce production costs and innovate" (p. 3). Innovation studies generally discern consecutive stages in the innovation process (Saren 1984; Galanakis 2006). The exact delineation of process stages depends on the type of innovation and the innovation theory subscribed to. However, in general there is an initiation stage followed by variants of conceptualization, research and development, adoption, and evaluation stages. Innovations are complex processes in which different actors, drivers and barriers have a part to play depending on the delivery stage.

The currently available guidance for business support on resource efficiency and a circular economy does not yet define stages in the innovation process, but it is important to change this in the future. Our preliminary observations (in Section 3) suggest that in particular the guidance for the initiation stage in which business managers and owners explore circular economy solutions should be expanded with a broader range of arguments that go beyond the purely economic to attract their initial interest for circular economy. Current guidance, such as that provided by the European Commission and Ellen MacArthur Foundation (Section 4.1), suggests companies should be tempted primarily by the potential for cost savings and business growth. The initiation stage of the innovation process should be clearly delineated and be sensitive to the diverse motivations of business owners and managers. Otherwise, the $22 \%$ of UK SMEs that are socially orientated (discussed in Section 2.1), and similarly minded businesses around the globe, may fail to be drawn to a circular economy and the significant potential benefits outlined above.

During the further conceptualization and research and development phases that take place in the process of implementing an innovative circular economy practice, companies are likely to encounter different drivers and barriers. The general drivers and barriers are better understood and include e.g., drivers in the form of increased resource security and lower resource sourcing and waste management costs, and barriers in the form of circular economy expertise and challenges covering initial investment costs (European Commission 2016). It is however still notable that social considerations, whether drivers or barriers, are under-developed. Guidance from the EU is limited to general statements around social acceptance of products and services, access to new markets, reputational benefits, and attracting committed employees (see European Commission 2016). Not only does this fail to fully capitalize on the willingness of companies to contribute to stronger communities and livelihoods, it is also out of tune with the aims of regional development policy to improve economic, social and territorial cohesion. Similarly, the Ellen McArthur Foundation (The Ellen MacArthur Foundation 2015b) admits that the direct contribution of a circular economy to poverty alleviation and social cohesion is yet to be demonstrated. Further theoretical and empirical research on the manners in which a circular economy can deliver social benefits is thus necessary within the inter-disciplinary subject area of a circular economy.

\subsection{Open Investigation into the Motivations of Companies to Explore a Circular Economy}

In summary, current circular economy business support guidance has been based on research into general drivers and barriers for companies in the adoption of more resource efficient practices, supplemented by case studies of successful approaches to support businesses such as the facilitation of waste-to-resource innovation by the UK's National Industrial Symbiosis Program and the promotion of eco-design by SMEs via the Enterprise Europe Network (European Commission 2015, 2016). No evidence was found of comprehensive investigations that analyzed the initial motivations of business managers and owners to explore circular economy practices for their company. Also, it is important to note that circular economy guidance documents do not indicate whether the initial motivations of SMEs and large (multi)nationals have been taken on board in the development of guidance for business support providers. 
EU guidance on circular economy adoption apparently presumes the dominance of economic motivations and reinforces the typical image of business as egoistic profit driven entities. This characterization of business is not exclusively wrong and will resonate with some. However, practitioner experience and wider reported evidence discussed in Section 3 of this article suggests that, in reality, business managers make up a diverse group of people with wide-ranging personalities and interests. Guidance has to be evidence-based and not based on tired stereotypes of business behavior. There is a risk that without government support companies remain stuck in old growth centered narratives (Velenturf and Jopson 2019), but with the current business support that is on offer, that risk may be equally high. In this way companies are being guided to continue to work from the narrow basis of the cost reductions offered by increased recycling and to motivate themselves and investors based on economic returns on investment (Mativenga et al. 2017), rather than delivering social, environmental and economic benefits in an integrated, sustainable manner (Velenturf and Jopson 2019).

An open, holistic investigation should be carried out into the diverse motivations of business owners and managers to explore and adopt circular economy practices. Such research would provide an evidence base for the development of more inclusive business support guidance from an open conception of the role of business in society and associated diverse motivations. Guidance that suitably resonates with the increasingly nuanced motivations of business managers and owners has a better chance to realize the full potential of circular economy opportunities.

Author Contributions: Conceptualization, A.P.M.V.; writing-original draft preparation, A.P.M.V., P.D.J. and N.E.; writing-review and editing, A.P.M.V., P.P., P.D.J., J.J. and N.E.; project administration J.J., A.P.M.V.; funding acquisition, P.P., A.P.M.V., J.J.

Funding: This research was funded by the Resource Recovery from Waste programme which is convened with funding from the Natural Environment Research Council, Economic and Social Research Council and Department for Environment, Food and Rural Affairs via the Complex Value Optimisation for Resource Recovery grant NE/L014149/1. The APC was funded by Administrative Sciences.

Conflicts of Interest: The authors declare no conflict of interest.

\section{References}

Accenture, and UN Global Compact. 2013. The UN global compact-accenture CEO study on sustainability 2013. Available online: https://www.unglobalcompact.org/docs/news_events/8.1/UNGC_Accenture_CEO_Study_ 2013.pdf (accessed on 30 August 2019).

Amor-Esteban, Victor, M.-Purifacación Galindo-Villardón, and Fátima David. 2018. Study of the Importance of National Identity in the Development of Corporate Social Responsibility Practices: A Multivariate Vision. Administrative Sciences 8: 50. Available online: https://www.mdpi.com/2076-3387/8/3/50 (accessed on 30 August 2019). [CrossRef]

Augenstein, Karoline, and Alexandra Palzkill. 2016. The Dilemma of Incumbents in Sustainability Transitions: A Narrative Approach. Administrative Sciences. Administrative Sciences 6: 1. Available online: https: //www.mdpi.com/2076-3387/6/1/1 (accessed on 30 August 2019). [CrossRef]

Bocken, Nancy, and Samuel Short. 2016. Towards a sufficiency-driven business model: Experiences and opportunities. Environmental Innovation and Societal Transitions 18: 41-61. [CrossRef]

Business in the Community. 2018. Resource Productivity and the Circular Economy: The opportunities for the UK economy. Available online: https://www.bitc.org.uk/sites/default/files/resource_productivity_and_the_ circular_economy_opportunities_for_the_uk_economy-compressed_1.pdf (accessed on 30 August 2019).

Circle Economy. 2019. The circularity gap report 2019. Available online: https://docs.wixstatic.com/ugd/ad6e59_ ba1e4d16c64f44fa94fbd8708eae8e34.pdf (accessed on 30 August 2019).

Department for Digital, Culture, Media and Sport, and Department for Business, Energy and Industrial Strategy. 2017. Social enterprise: Market trends 2017. Available online: https://assets.publishing.service.gov.uk/government/ uploads/system/uploads/attachment_data/file/644266/MarketTrends2017report_final_sept2017.pdf (accessed on 30 August 2019). 
Department for Environment, Food and Rural Affairs. 2018. Resources and waste strategy for England. Available online: https://www.gov.uk/government/publications/resources-and-waste-strategy-for-england (accessed on 30 August 2019).

Doherty, Bob, Helen Haugh, and Fergus Lyon. 2014. Social enterprises as hybrid organisations: A review and research agenda. International Journal of Management Reviews 16: 417-36. Available online: https: //onlinelibrary.wiley.com/doi/full/10.1111/ijmr.12028 (accessed on 2 September 2019). [CrossRef]

Dyllick, Thomas, and Katrin Muff. 2015. Clarifying the Meaning of Sustainable Business: Introducing a Typology from Business-as-Usual to True Business Sustainability. Organization E Environment 29: 1-19.

European Commission. 2015. A framework for Member States to support business in improving its resource efficiency. Available online: https://www.ecologic.eu/sites/files/publication/2015/re_in_business_final_ report_111115.pdf (accessed on 30 August 2019).

European Commission. 2016. Improving resource efficiency in SMEs. Available online: http://www.ggb.gr/sites/default/files/basic-page-files/Guidebooks_10_Improving\%20resource\% 20efficiency\%20in\%20SMEs_2016.pdf (accessed on 30 August 2019).

European Commission. n.d.a. Circular economy. Available online: https://ec.europa.eu/growth/industry/ sustainability/circular-economy_en (accessed on 6 September 2019).

European Commission. n.d.b. European structural and investment funds (ESI funds)—Explore our data. Available online: https://cohesiondata.ec.europa.eu/ (accessed on 6 September 2019).

European Union. 2015. Closing the loop-An EU action plan for the Circular Economy. Available online: https:/eur-lex.europa.eu/legal-content/EN/TXT/HTML/?uri=CELEX:52015DC0614\&from=EN (accessed on 30 August 2019).

European Union. 2018. Small and medium enterprises: An overview. Available online: https://ec.europa.eu/ eurostat/web/products-eurostat-news/-/EDN-20181119-1 (accessed on 30 August 2019).

European Union. 2019. European Regional Development Fund. Available online: https://ec.europa.eu/regional_ policy/en/funding/erdf/ (accessed on 6 September 2019).

Evan, William M., and Edward R. Freeman. 1993. A stakeholder theory of the modern corporation: Kantian capitalism. In Ethical Theory and Business, 4th ed. Edited by Tom L. Beauchamp and Norman E. Bowie. Englewood Cliffs: Prentice Hall.

Foschi, Eleonora, and Allesandra Bonoli. 2019. The Commitment of Packaging Industry in the Framework of the European Strategy for Plastics in a Circular Economy. Administrative Sciences 9: 18. Available online: https://www.mdpi.com/2076-3387/9/1/18 (accessed on 30 August 2019). [CrossRef]

Friedman, Milton. 1962. Capitalism and Freedom. Chicago: University of Chicago.

Friedman, Milton. 1970. The Social Responsibility of Business is to Increase Its Profits. New York Times Magazine, September 13.

Galanakis, K. 2006. Innovation process. Make sense using systems thinking. Technovation 26: 1222-32. Available online: https://www.sciencedirect.com/science/article/pii/S0166497205001057 (accessed on 2 September 2019). [CrossRef]

Geissdoerfer, Martin, Paulo Savaget, Nancy M.P. Bocken, and Erik Jan Hultink. 2017. The circular economy-A new sustainability paradigm? Journal of Cleaner Production 143: 757-68. Available online: https://www. sciencedirect.com/science/article/pii/S0959652616321023 (accessed on 15 July 2019). [CrossRef]

Ghisellini, Patrizia, Catia Cialani, and Sergio Ulgiati. 2016. A review on circular economy: The expected transition to a balanced interplay of environmental and economic systems. Journal of Cleaner Production 114: 11-32. Available online: https://www.sciencedirect.com/science/article/pii/S0959652615012287 (accessed on 15 July 2019). [CrossRef]

Global Reporting Initiative. 2015. Informing decisions, driving change: The role of data in a sustainable future. Available online: https:/www.globalreporting.org/resourcelibrary/Informing-decisions,-driving-changeThe-role-of-data-in-a-sustainable-future.pdf (accessed on 30 August 2019).

Global Reporting Initiative, and UN Global Compact. n.d. Business reporting on the SDGS: An analysis of the goals and targets. Available online: https://www.globalreporting.org/resourcelibrary/GRI_UNGC_BusinessReporting-on-SDGs_Analysis-of-Goals-and-Targets.pdf (accessed on 30 August 2019).

Green Alliance, and WRAP. 2016. Employment and the circular economy: Job creation in a more resource efficient Britain. Available online: http://www.wrap.org.uk/sites/files/wrap/Employment\%20and\%20the\%20circular\% 20economy\%20summary.pdf (accessed on 2 September 2019). 
Green Alliance, and CIE-MAP. 2018. Less in, more out: Using resource efficiency to cut carbon and benefit the economy. Available online: https://www.green-alliance.org.uk/less_in_more_out.php (accessed on 2 September 2019).

Hoffman, Andrew J., Charles J. Corbett, Nitin Joglekar, and Peter Wells. 2014. Industrial Ecology as a Source of Competitive Advantage. Journal of Industrial Ecology 18: 597-602. Available online: https: //onlinelibrary.wiley.com/toc/15309290/2014/18/5 (accessed on 15 July 2019). [CrossRef]

Jensen, Paul D. 2015. Engineering Skills Support for the Workforce: York, North Yorkshire and the East Riding. Beverley: Energy Technology Centre, Available online: https://www.researchgate.net/publication/ 336197870_Engineering_Skills_for_the_Workforce_York_North_Yorkshire_and_the_East_Riding (accessed on 10 October 2019).

Jensen, Paul D. 2016. The role of geospatial industrial diversity in the facilitation of regional industrial symbiosis. Resources, Conservation and Recycling 107: 92-103. Available online: https://www.sciencedirect.com/science/ article/pii/S0921344915301440 (accessed on 15 July 2019). [CrossRef]

Jensen, Paul D., Lauren Basson, Emma E. Hellawell, Malcolm Bailey, and Matthew A. Leach. 2011. Quantifying 'geographic proximity': Experiences from the United Kingdom's National Industrial Symbiosis Programme. Resources, Conservation and Recycling 55: 703-12. Available online: https://www.sciencedirect.com/science/ article/pii/S0921344911000243 (accessed on 15 July 2019). [CrossRef]

Kirchherr, Julian, Denise Reike, and Marko Hekkert. 2017. Conceptualising the circular economy-An analysis of 114 definitions. Resources, Conservation and Recycling 127: 221-32. Available online: https://www.sciencedirect. com/science/article/pii/S0921344917302835 (accessed on 15 July 2019). [CrossRef]

Kiser, Barbara. 2016. Circular economy: Getting the circulation going. Nature 53: 443-46. Available online: https://www.nature.com/articles/531443a (accessed on 15 July 2019).

Korhonen, Jouni, Cali Nuur, Andreas Feldmann, and Seyoum Eshetu Birkie. 2018. Circular economy as an essentially contested concept. Journal of Cleaner Production 175: 544-52. [CrossRef]

Lacy, Peter, and Jakob Rutqvist. 2014. Waste to Wealth: Creating Advantage in a Circular Economy. London: Palgrave Macmillan.

Lehtoranta, Suvi, Ari Nissinen, Tuomas Mattila, and Matti Melanen. 2011. Industrial symbiosis and the policy instruments of sustainable consumption and production. Journal of Cleaner Production 19: 1865-75. Available online: https://www.sciencedirect.com/science/article/pii/S0959652611001181 (accessed on 15 July 2019). [CrossRef]

Madsen, Kjær Madsen, Nils Boisen, Lousie Udsen Nielsen, and Lousie Holmelund Tackmann. 2015. Industrial Symbiosis Exchanges: Developing a Guideline to Companies. Waste Biomass Valor 6: 855-64. Available online: https://link.springer.com/article/10.1007/s12649-015-9417-9 (accessed on 15 July 2019). [CrossRef]

Marshall, Rachel, Anne Velenturf, and Juliet Jopson. 2018. Making the Most of Industrial Wastes: Strengthening Resource Security of Valuable Metals for Clean Growth in the UK. Policy and Practice Note. Leeds: Resource Recovery from Waste.

Mativenga, Paul T., Al Amin Mohamed Sultan, John Agwa-Ejon, and Charles Mbohwa. 2017. Composites in a Circular Economy: A Study of United Kingdom and South Africa. Procedia CIRP 61: 691-96. Available online: https://www.sciencedirect.com/science/article/pii/S2212827117302718 (accessed on 15 July 2019). [CrossRef]

McKinsey, and the Ellen Macarthur Foundation. 2015. Growth Within: A Circular Economy Vision for a Competitive Europe. New York: McKinsey, Available online: https://www.mckinsey.com/business-functions/sustainability/ our-insights/europes-circular-economy-opportunity (accessed on 2 September 2019).

Merli, Roberto, Michele Preziosi, and Alessia Acampora. 2018. How do scholars approach the circular economy? A systematic literature review. Journal of Industrial Ecology 178: 703-22. [CrossRef]

Greenwood, Michelle. 2001. The Importance of Stakeholders According to Business Leaders. Business E Society Review 106: 29-49.

Mintzberg, Henry. 1983. The case for corporate social responsibility. Journal of Business Strategy 4: 3-15. [CrossRef]

Moon, Jeremy. 1995. The Firm as Citizen: Corporate Responsibility in Australia. Australian Journal of Political Science 30: 1-17. [CrossRef]

Moreau, Vincent, Marlyne Sahakian, Pascal van Griethuysen, and François Vuille. 2017. Coming Full Circle: Why Social and Institutional Dimensions Matter for the Circular Economy. Journal of Industrial Ecology 21: 497-506. Available online: https://onlinelibrary.wiley.com/doi/full/10.1111/jiec.12598 (accessed on 15 July 2019). [CrossRef] 
Murray, Alan, Keith Skene, and Kathryn Haynes. 2017. The circular economy: An interdisciplinary exploration of the concept and application in a global context. Journal of Business Ethics 140: 369-80. Available online: https://link.springer.com/article/10.1007/s10551-015-2693-2 (accessed on 15 July 2019). [CrossRef]

National Industrial Symbiosis Program. 2009. The Pathway to A Low Carbon Sustainable Economy. Available online: http://www.wrap.org.uk/sites/files/wrap/Pathway\%20Report.pdf (accessed on 2 September 2019).

National Industrial Symbiosis Program. n.d. Available online: https://www.international-synergies.com/projects/ national-industrial-symbiosis-programme/ (accessed on 2 September 2019).

Nyssens, Marthe, ed. 2006. Social Enterprise. London: Routledge.

Post, Frederick R. 2003. Response to 'The social Responsibility of Corporate Management: A Classical Critique'. Mid-American Journal of Business 18: 25-35. [CrossRef]

Rappaport, Alfred. 1986. Creating Shareholder Value: A Guide for Managers and Investors: The New Standard for Business Performance. New York: Free Press.

Raworth, Kate. 2017. Doughnut Economics: Seven Ways to Think Like a 21st-Century Economist. London: Random House Business Books.

Saren, Michael A. 1984. A classification and review of models of the intra-firm innovation process. RED Management 14: 11-25. Available online: https://onlinelibrary.wiley.com/doi/epdf/10.1111/j.1467-9310.1984.tb00504.x (accessed on 15 July 2019).

Scholes, Eileen, and David Clutterbuck. 1998. Communication with stakeholders: An integrated approach. Long Range Planning 31: 227-38. [CrossRef]

Schroeder, Patrick, Kartika Anggraeni, and Uwe Weber. 2018. The Relevance of Circular Economy Practices to the Sustainable Development Goals. Journal of Industrial Ecology 23: 77-95. Available online: https: //onlinelibrary.wiley.com/doi/full/10.1111/jiec.12732 (accessed on 15 July 2019). [CrossRef]

Schroeder, Patrick, Magnus Bengtsson, Maurie Cohen, Paul Dewick, Joerg Hoffstetter, and Joseph Sarkis. 2019. Degrowth within-Aligning Circular Economy and Strong Sustainability Narratives. Resources, Conservation and Recycling 146: 190-91. Available online: https://www.sciencedirect.com/science/article/pii/ S0921344919301429 (accessed on 15 July 2019). [CrossRef]

SEUK. 2017. State of Social Enterprise Report 2017. Available online: https://www.socialenterprise.org.uk/stateof-social-enterprise-reports/the-future-of-business-state-of-social-enterprise-survey-2017/ (accessed on 30 August 2019).

Simboli, Alberto, Raffaella Taddeo, and Anna Morgante. 2014. Value and Wastes in Manufacturing. An Overview and a New Perspective Based on Eco-Efficiency. Administrative Sciences 4: 173-191. Available online: https://www.mdpi.com/2076-3387/4/3/173 (accessed on 2 September 2019). [CrossRef]

Stahel, Walter. 2016. The Circular Economy. Nature 531: 435-38. [CrossRef] [PubMed]

Sternberg, Elaine. 1997. The Defects of Stakeholder Theory. Corporate Governance 5: 3-10. [CrossRef]

Sternberg, Elaine. 1998. Corporate Governance: Accountability in the Market Place. London: The Institute of Economic Affairs.

Stevens, Robin, Nathalie Moray, and Johan Bruneel. 2015. The Social and Economic Mission of Social Enterprises: Dimensions, Measurement, Validation, and Relation. Entrepreneurship Theory and Practice 39: 1051-82. Available online: https://journals.sagepub.com/doi/full/10.1111/etap.12091 (accessed on 15 July 2019). [CrossRef]

Suarez-Eiroa, Brais, Emilio Fernandez, Gonzalo Mendez-Martinez, and David Soto-Onate. 2019. Operational principles of circular economy for sustainable development: Linking theory and practice. Journal of Cleaner Production 214: 952-61. Available online: https://www.sciencedirect.com/science/article/pii/ S0959652618340009 (accessed on 15 July 2019). [CrossRef]

The Ellen MacArthur Foundation. 2015a. Towards a circular economy: Business rational for an accelerated transition. Available online: https://www.ellenmacarthurfoundation.org/assets/downloads/TCE_EllenMacArthur-Foundation_9-Dec-2015.pdf (accessed on 30 August 2019).

The Ellen MacArthur Foundation. 2015b. Delivering the circular economy: A toolkit for policymakers. Available online: https://www.ellenmacarthurfoundation.org/assets/downloads/publications/ EllenMacArthurFoundation_PolicymakerToolkit.pdf (accessed on 30 August 2019).

The Ellen MacArthur Foundation. 2017. Achieving growth within. Available online: https://www. ellenmacarthurfoundation.org/assets/downloads/publications/Achieving-Growth-Within-20-01-17.pdf (accessed on 30 August 2019). 
The Ellen MacArthur Foundation. 2019. The circular economy 100. Available online: https://www. ellenmacarthurfoundation.org/our-work/activities/ce100 (accessed on 30 August 2019).

United Nations Environment Program. 2016. Global Material Flows and Resource Productivity: Assessment Report for the UNEP International Resource Panel. Available online: http://unep.org/documents/irp/1600169_LW_GlobalMaterialFlowsUNEReport_FINAL_160701.pdf (accessed on 15 July 2019).

United Nations Environment Program, and International Solid Waste Association. 2015. Global Waste Management Outlook. Available online: http://apps.unep.org/publications/index.php?option=com_pub\& task=download\&file=011782_en (accessed on 15 July 2019).

Velenturf, Anne P.M., and Paul D. Jensen. 2017. Proceedings of the Stakeholder Workshop on Agricultural and Food Processing Waste Sustainable Supply Chains, Lleida, Spain, September 28; Deliverable 8.5, Agrimax Project. Available online: http://agrimax-project.eu/files/2017/05/AgriMAX-Stakeholder-Workshop-Proceedings_ final.pdf (accessed on 15 July 2019).

Velenturf, Anne P.M., and Juliet S. Jopson. 2019. Making the business case for resource recovery. Science of the Total Environment 648: 1031-41. [CrossRef]

Velenturf, Anne P.M., and Phil Purnell. 2018. Delivering Radical Change in Waste and Resource Management: Industry Priorities. Leeds: Resource Recovery from Waste.

Vermeulen, Walter. 2015. Self-Governance for Sustainable Global Supply Chains: Can it Deliver the Impacts Needed? Business Strategy and the Environment 24: 73-85. [CrossRef]

Whysall, Paul. 2000. Addressing ethical issues in retailing: A Stakeholder Perspective. International Review of Retail Distribution and Consumer Research 10: 305-18. [CrossRef]

World Bank. n.d. World Bank National Accounts Data, and OECD National Accounts Data Files. Available online: https://data.worldbank.org/indicator/NY.GDP.MKTP.CD (accessed on 6 September 2019).

(C) 2019 by the authors. Licensee MDPI, Basel, Switzerland. This article is an open access article distributed under the terms and conditions of the Creative Commons Attribution (CC BY) license (http://creativecommons.org/licenses/by/4.0/). 